\title{
Molecular characterization and interviral relationships of a flexuous filamentous virus causing mosaic disease of sugarcane (Saccharum officinarum L.) in India*
}

\author{
M. Hema ${ }^{1}$, J. Joseph ${ }^{2}$, K. Gopinath ${ }^{2, * *}$, P. Sreenivasulu ${ }^{1}$, and H. S. Savithri ${ }^{2}$ \\ ${ }^{1}$ Department of Virology, Sri Venkateswara University, Tirupati, Andhra Pradesh, India \\ ${ }^{2}$ Department of Biochemistry, Indian Institute of Science, Bangalore, Karnataka, India
}

Accepted October 12, 1998

Summary. A virus isolate causing mosaic disease of commercial sugarcane was purified to homogeneity. Electron microscopy revealed flexuous filamentous virus particles of ca $890 \times 15 \mathrm{~nm}$. The virus isolate reacted positively with heterologous antiserum to narcissus latent virus form UK, but failed to react with potyvirus group specific antiserum. $\mathrm{N}$-terminal sequencing of the intact coat protein $(\mathrm{CP})$ and the tryptic peptides indicated that the virus was probably a potyvirus but distinct from several reported potyviruses. Comparison of the 3'-terminal 1084 nucleotide sequence of the RNA genome of this virus revealed $93.6 \%$ sequence identity in the coat protein coding region with the recently described sugarcane streak mosaic virus (Pakistani isolate). The molecular weight of the coat protein $(40 \mathrm{kDa})$ was higher than that deduced from the amino acid sequence $(34 \mathrm{kDa})$. The apparent increase in size was shown to be due to glycosylation of the coat protein which has not been reported thus far in the family, Potyviridae. This is the first report on the molecular characterization of a virus causing mosaic disease of sugarcane in India and the results demonstrate that the virus is a strain of sugarcane streak mosaic virus, a member of the Tritimovirus genus of the Potyviridae. We have named it sugarcane streak mosaic virus - Andhra Pradesh isolate (SCSMV-AP).

*The nucleotide sequence reported in this paper has been submitted to GenBank and assigned the accession number Y17738.

${ }^{* *}$ Present address: Department of Molecular Biology, Wageningen Agricultural University, Wageningen, The Netherlands. 


\section{Introduction}

Sugarcane (Saccharum officinarum L.) is an important industrial cash crop accounting for about $60 \%$ sugar production in the world, and India ranks as one of the top producers of cane sugar [4]. The viruses reported to infect sugarcane naturally are Badnavirus (Caulimoviridae) sugarcane bacilliform badna virus (SCBV), Fijivirus (Reoviridae) Fiji disease virus (FDV), Monogeminivirus (Geminiviridae) sugarcane streak virus (SSV), Potyvirus (Potyviridae) sugarcane mosaic virus (SCMV), sorghum mosaic virus (SrMV) [3, 12, 17].

The main characteristics considered to define a potyvirus are particle morphology, cytopathology, mode of transmission and molecular characteristics such as genome structure and organization, coat protein sequence and serology [27]. When the complete sequence of the potyvirus genome is difficult to generate, partial nucleotide sequences covering 3 '-untranslated region (UTR) and coat protein coding region are useful in distinguishing strains of a virus from distinct potyviruses [5]. Immunological studies using antibodies to $\mathrm{N}$-terminal and core region of coat proteins and high performance liquid chromatography (HPLC) peptide profiling of coat proteins have lead to delineation of 17 SCMV/MDMV (maize dwarf mosaic virus) strains from Australia and the United States into four distinct potyviruses namely SCMV, SrMV, MDMV and johnsongrass mosaic virus (JGMV). It has been suggested that all these viruses should be grouped as a sugarcane mosic virus subgroup in the genus Potyvirus [24]. Recently, reverse transcription-polymerase chain reaction (RT-PCR) based restriction fragment length polymorphism (RFLP) analysis was developed for rapid discrimination between strains of SCMV and SrMV occurring in the United States [28]. The status of the different strains of these viruses reported from other countries is uncertain and needs to be thoroughly investigated.

Several isolates of sugarcane mosaic virus subgroup causing mosaic disease of sugarcane, maize, sorghum, pearl millet and finger millet have been reported from different parts of India $[8,11,15,19]$. The virus isolates have been identified based on differences in physical properties, host range, particle morphology and limited serological data. None of these isolates have been characterized at molecular level. Recently, immunological characterization of a virus causing mosaic disease of sugarcane in Andhra Pradesh, India revealed that it is probably distinct from SCMV [8].

Virus isolate(s) causing mosaic disease of sugarcane in India continue to be a potential threat to the sugarcane industry as it is a very common disease in almost all sugarcane growing regions because of the perpetuation of the disease causing virus through vegetative propagules (setts) [1].

In the present study, we report the molecular characterization of a virus causing mosaic disease of sugarcane in Andhra Pradesh, India. The 3'-terminal 1084 nucleotide sequence of the viral RNA genome showed $85.7 \%$ identity with a recently reported Tritimovirus (Potyviridae) sugarcane streak mosaic virus originating from Pakistan [7]. Molecular data on this viral genome is essential to develop primers necessary for RT-PCR and RFLP based discrimination of virus 
isolates and to develop molecular diagnostic methods for detection of the virus, especially in the planting sugarcane material.

\section{Materials and methods}

\section{Virus propagation}

The virus isolate used in this study was collected from commercial sugarcane fields in Chittoor district of Andhra Pradesh (A.P.), India [13]. This was subsequently propagated on Sorghum bicolor cv. Rio plants grown in a glass house by periodical sap inoculation [8].

\section{Virus purification}

Infected sorghum leaves harvested 15 days post-inoculation were homogenized in three volumes of $0.02 \mathrm{M} \mathrm{N}$-(2-Hydroxyethyl) piperizine- $\mathrm{N}^{\prime}$-(2-ethanesulfonic acid) (HEPES) buffer, $\mathrm{pH} 8.0$ containing $0.01 \mathrm{M}$ ethylenediamine tetraacetic acid (EDTA), $0.1 \mathrm{M}$ urea and $0.2 \% 2$-mercaptoethanol (v/v) and the extract was filtered through muslin cloth. The filtrate was clarified by the addition of chloroform and carbon tetrachloride $(1: 1 \mathrm{v} / \mathrm{v}, 30 \%)$ and stirred for $30 \mathrm{~min}$. This was followed by low speed centrifugation at 7,800 $\mathbf{g}$ for $10 \mathrm{~min}$. Triton X-100 was added to the supernatant to a final concentration of $2 \%$ and stirred for $1 \mathrm{~h}$. The virus in the aqueous phase was pelleted by centrifugation at $140,000 \mathrm{~g}$ for $3 \mathrm{~h}$ using Sorvall AH-629 rotor. The virus pellet was resuspended in 0.02 M HEPES buffer, pH 7.2 (resuspension buffer) overnight at $4{ }^{\circ} \mathrm{C}$. It was centrifuged at $4,400 \mathrm{~g}$ for $5 \mathrm{~min}$, supernatant layered on preformed $20-50 \%$ sucrose density gradients prepared in resuspension buffer, and centrifuged at $120,000 \mathrm{~g}$ for $2 \mathrm{~h}$ using Sorvall AH-629 rotor. The light scattering zone was collected, diluted three times with resuspension buffer and pelleted at $145,000 \mathrm{~g}$ for $2 \mathrm{~h}$ using Sorvall T 1250 rotor. The final purified virus pellet was resuspended in minimal volume of resuspension buffer and a fraction of it was scanned in UV-visible spectrophotometer from 200-300 nm [10]. Infectivity of purified virus was checked by inoculating it on healthy S. bicolor cv. Rio plants.

\section{Electron microscopy}

Carbon shadowed formvar coated grids applied with purified virus particles were negatively stained with $1 \%$ phosphotungstic acid (w/v) in water and observed under Philips 301 electron microscope $(50,000 \times)$.

\section{Serology}

Serological relationships of this virus isolate using antisera against narcissus latent virus and potyvirus group specific antiserum [16] were investigated by employing direct antigen coating enzyme-linked immunosorbant assay (DAC-ELISA) [9]. In DAC-ELISA, leaf antigens were extracted in coating buffer $(1: 10 \mathrm{w} / \mathrm{v} ; 200 \mu \mathrm{l} /$ well $)$ and purified virus $(200 \mathrm{ng} / \mathrm{well})$ were used. The primary antibodies were used at a dilution of 1:500 and goat anti-rabbit IgG conjugated to alkaline phosphatase at 1:1000 dilution was used as the secondary antibody. The reaction was developed using p-nitrophenyl phosphate (PNP) and the absorbance was measured at $405 \mathrm{~nm}$ in a Biotek Ceres 900 ELISA Reader.

\section{Glycoprotein staining}

Glycoprotein staining of virus coat protein in polyacrylamide gel was performed as described earlier [29]. Physalis mottle virus coat protein $(20 \mathrm{kDa})$ and trehalase from Thermomyces lanuginosis RM-B strain (145 kDa) were used as negative and positive controls, respectively. 


\section{Partial sequence analysis of coat protein}

Coat protein was isolated from purified virus suspended in 0.01 M HEPES buffer, pH 7.2 $(10 \mathrm{mg} / \mathrm{ml})$ [26]. The purity and homogeneity of coat protein was checked by $12 \%$ SDS-PAGE [14].

Purified virus was digested with trypsin $\left(50 \mu \mathrm{g} / \mathrm{mg}\right.$ purified virus) at $37^{\circ} \mathrm{C}$ for $30 \mathrm{~min}$. The tryptic peptides were separated by $12 \%$ tricine gel electrophoresis [22]. The gel was rinsed in tris-glycine buffer containing $20 \%$ methanol for $15 \mathrm{~min}$ and electroblotted onto Poly(vinylidene difluoride) (PVDF) membrane (Millipore) using Novablot apparatus (Pharmacia). After transfer, the PVDF membrane was stained for 5 min with Ponceau S, destained with water and air dried. The relevant bands were cut and loaded onto an automated gas phase protein sequenator PSQ-1 (Shimadzu).

\section{Isolation of viral RNA}

Infectious RNA was isolated by disruption method from freshly purified virus preparations as described [30]. The RNA pellet was resuspended in diethyl pyrocarbonate (DEPC) treated sterile water. The RNA was separated on $1 \%$ agarose gel using Tris-borate-EDTA buffer, $\mathrm{pH}$ 8.3 [20]. The infectivity of the RNA was checked by inoculating it to 10-15 days old healthy sorghum cv. Rio plants under sterile conditions.

\section{cDNA synthesis and cloning}

Isolated RNA was treated with RNase-free DNase (Boehringer Mannheim; 1 unit/reaction) at room temperature for $15 \mathrm{~min}$, re-extracted with phenol-chloroform mixture and precipitated with isopropanol. The precipitated RNA was resuspended in $10 \mu \mathrm{l}$ of DEPC treated sterile water and used immediately for cDNA synthesis using SuperScriptII reverse transcriptase and oligo dT primers (GIBCO-BRL) as per the manufacturer's instructions. The cDNA was fractionated on a Sephacryl S-1000 column (Sigma) and ligated to Hinc II cut pUC 19 vector at $16{ }^{\circ} \mathrm{C}$ for $12 \mathrm{~h}$. Cloned cDNA was transformed into competent $E$. coli DH5 $\alpha$ cells and recombinant clones were screened by blue/white colony selection [20]. Further screening of cDNA clones specific to viral RNA was carried out by colony hybridization [6] using labeled first strand cDNA as probe.

\section{DNA sequencing and analysis}

The cDNA clones were sequenced according to Sanger's method [21] using Sequenase version 2.0 (Amersham) and M13 forward and reverse primers manually as well as by automated ABI Prism DNA sequencer. The sequences were analyzed using the Wisconsin package (version 9.1) programs.

\section{Results}

\section{Virus purification and particle morphology}

The major problem encountered during purification was the aggregation of the virus particles and loss of the virus in low speed centrifugation. The procedure described in the methods helped to minimize these problems and lead to virus preparation relatively free of host contaminants. The purified virus particles had an $\mathrm{A}_{260 / 280}$ ratio of 1.13 and the yields were approximately $10 \mathrm{mg} / \mathrm{kg}$ leaf tissue. Electron microscopy of the purified virus preparations (Fig. 1) showed that the particles were flexuous rods with an average dimension of $890 \times 15 \mathrm{~nm}$, similar to the members of the family Potyviridae. 


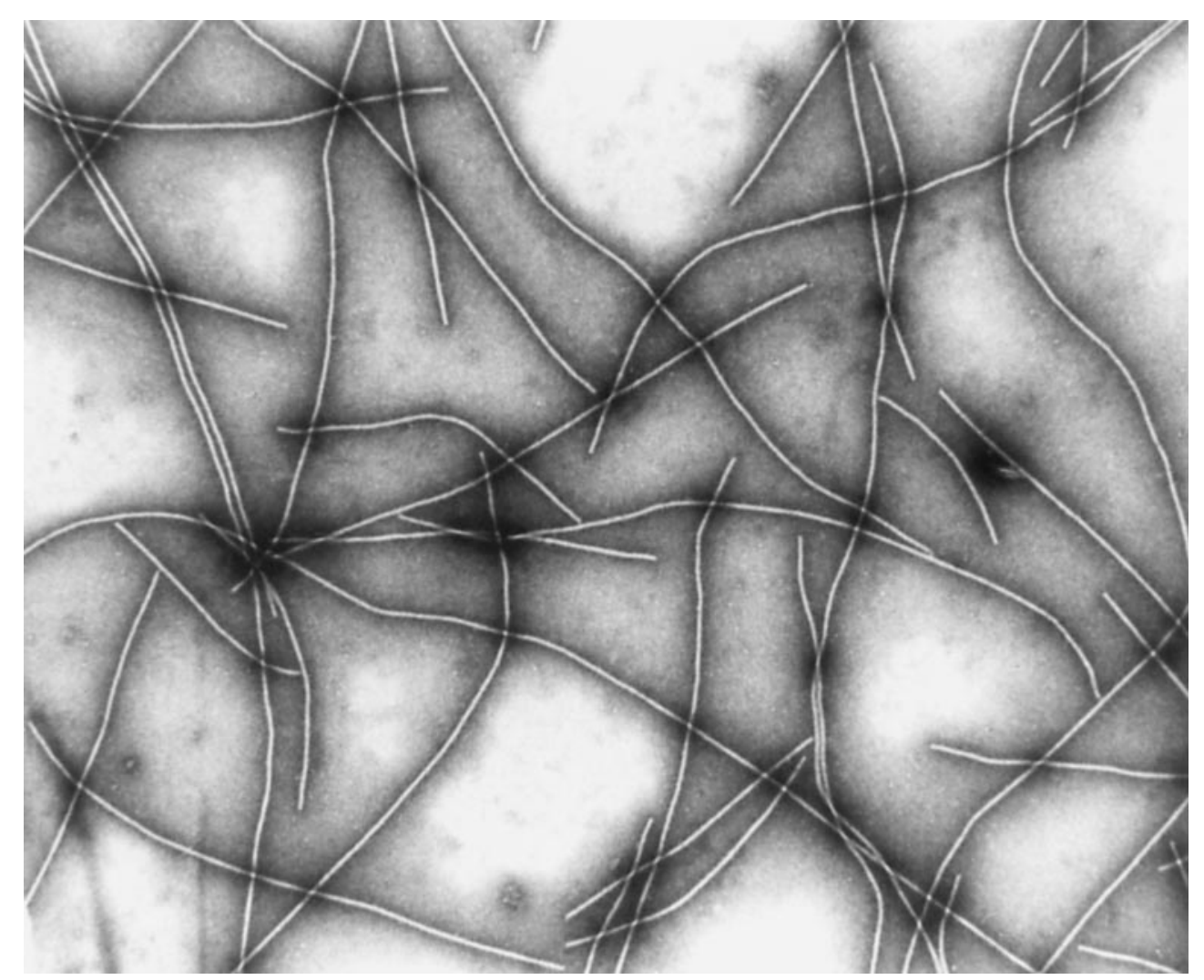

Fig. 1. Electron micrograph of purified virus particles causing mosaic disease on sugarcane were stained with $1 \%$ phosphotungstic acid. Magnification $\times 50,000$

\section{Serology}

In an earlier study, we have shown that the virus does not cross react with many of the well characterized potyviruses including several SCMV strains [8]. When DAC-ELISA was carried out as described in the methods section, the virus did not cross react with potyvirus group specific antiserum but showed measurable reaction with narcissus latent virus, which has been suggested to be the member of Macluravirus, a new genus of the family Potyviridae [2] (Table 1). Further, these results also correlated well with EBIA analysis (data not shown).

\section{Analysis of viral coat protein and the tryptic peptides}

The purified virus resolved into two bands on 12\% SDS-PAGE corresponding to molecular weights $40 \mathrm{kDa}$ and $28.5 \mathrm{kDa}$ (Fig. 2a). The lower band could be a degradation product of the coat protein as observed in many potyviruses. Western analysis with homologous antiserum confirmed that the lower band was indeed a degradation product (data not shown). However, in the isolated coat protein, there were other bands apart from the two major bands ( $40 \mathrm{kDa}$ and $28.5 \mathrm{kDa}$ ) which could be the result of incomplete dissociation and degradation. The purified virus was subjected to mild trypsin treatment and transferred onto PVDF mambrane 
Table 1. Reaction of sugarcane virus with different antisera in DAC-ELISA

\begin{tabular}{llll}
\hline Antisera used & Purified virus & $\begin{array}{l}\text { Infected } \\
\text { sorghum leaf } \\
\text { tissue }\end{array}$ & $\begin{array}{l}\text { Healthy sorghum } \\
\text { leaf tisue }\end{array}$ \\
\hline Homologous & 3.69 & 1.38 & 0.22 \\
$\begin{array}{l}\text { Narcissus latent } \\
\text { Potyvirus group }\end{array}$ & 1.21 & 0.73 & 0.16 \\
specific & 0.02 & 0.08 & 0.04 \\
\hline
\end{tabular}

The numbers represent $\mathrm{A}_{405} \mathrm{~nm}$ reading of two experiments (in triplicate)

A
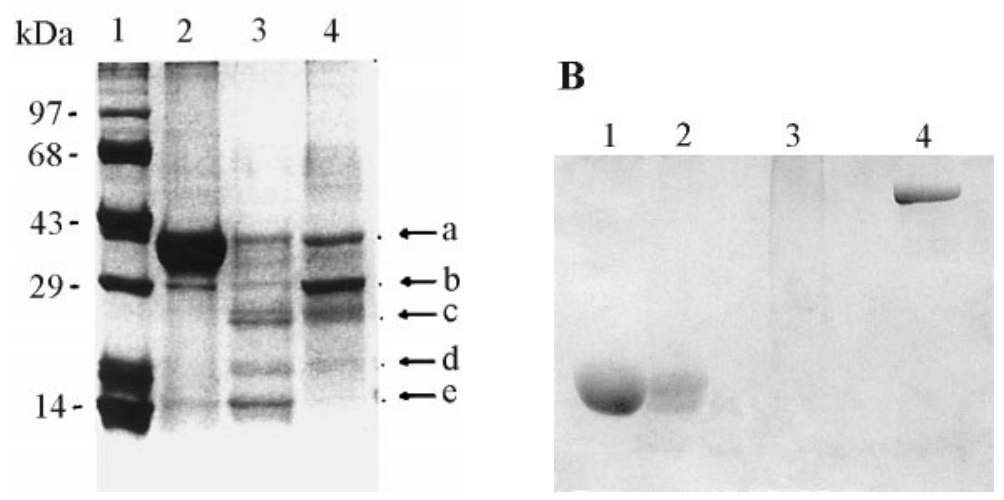

Fig. 2. SDS-PAGE analysis of sugarcane virus coat protein. A Tryptic peptide profile of the coat protein. Purified virus $(100 \mu \mathrm{g})$ was treated with trypsin $(50 \mu \mathrm{g} / \mathrm{mg})$ as described in Materials and methods. The arrows $(a-e)$ indicate the fragments used for sequencing after transferring a parallel gel onto PVDF membrane. ( $a$ intact coat protein, $b$ degraded product of coat protein, $c$ TP1, $d \mathrm{TP} 2, e \mathrm{TP} 3) .1$ Standard molecular weight markers; 2 intact purified virus; 3 purified virus treated with trypsin; 4 isolated coat protein. B Glycoprotein staining of the coat protein. The samples were separated on 12\% SDS-PAGE were stained for the presence of carbohydrate using PAS (periodic acid sulfate) staining. Sugarcane viral intact (1) and degraded (2) coat protein, PhMV coat protein (3) trehalase (4)

after SDS-PAGE (Fig. 2a) as described in the methods section. The N-terminal sequence analysis of the isolated coat protein, its degradation product and tryptic peptides obtained is shown in Table 2 . The analysis of the partial sequence data indicated that the sequence of TP 3 aligned well with the corresponding region in the trypsin resistant core of potyviruses (Table 3 ). The peptide TP 2 was impure and did not result in unambiguous sequence. When the sequences were compared with four strains of SCMV, it was found that the virus did not belong to this sub-group [24]. 
Table 2. Partial N-terminal amino acid sequence of the intact coat protein and the tryptic peptides of the virus isolated from sugarcane

\begin{tabular}{ll}
\hline & Amino acid sequence \\
\hline $\begin{array}{l}\text { Coat protein } \\
\text { Degradation } \\
\text { product }\end{array}$ & GQGTQPPQ \\
TP 1 & NTVSQTMRSLYVPPLVK \\
TP 3 & AVLNLDGAD \\
\hline
\end{tabular}

Table 3. Alignment of tryptic peptide (TP 3 ) of the sugarcane virus with other potyviruses

\begin{tabular}{ll}
\hline SCSMV-AP & NAKPGIRAIMRHFGELAYK \\
JGMV-JG & NAKPTLRQCMMHF SDAAEA \\
SCMV-B & NASPTFRQIMHHFSDAAEA \\
SrMV-SCI & YASPTFRQIMHHFSDAAEA \\
MDMV-A & NASPTFRQIMHHFSDAAEA \\
PVY & NAKPTLRQIMAHFSDVAEA \\
BaYMV & RMNGGLRRIMRNYSDETVL \\
RGMV & HAQPTLRSIMAHFSDAATA \\
SPMMV & NAQPTLRQVMRHFGEQAVA \\
NLV & VENGGLRKIMRHFSGITHE
\end{tabular}

The alignment was done by using already published sequences. JGMV-JG, SCMV-B, SrMV-SCI and MDMVA [28]; potato virus Y (PVY), barley yellow mosaic virus (BaYMV), ryegrass mosaic virus (RGMV), sweet potato mild mottle virus (SPMMV) and narcissus latent virus (NLV) [2]

\section{Characterization of viral genome}

The isolated RNA was found to be infectious upon mechanical inoculation on healthy sorghum plants and was used for cDNA synthesis. The recombinant plasmids harboring cDNA inserts $(0.3-1.5 \mathrm{~kb})$ were sequenced as described in the methods section. The authenticity of these clones were confirmed by manual sequencing which showed the presence of poly dT tracts.

The nucleotide sequence of pSV 7 was determined and it corresponded to $3^{\prime}$ terminal 495 nucleotides of the viral genome. The sequence of another clone pSV 5 overlapped with the $5^{\prime}$ sequence of pSV 7. Thus, $3^{\prime}$ terminal 1084 nucleotides of the viral genome could be compiled (Fig. 3). This sequence consisted of 193 nucleotides of $3^{\prime}$ untranslated region and a partial open reading frame. The partial ORF encompassed the complete coat protein sequence. The $\mathrm{N}$-terminal amino 


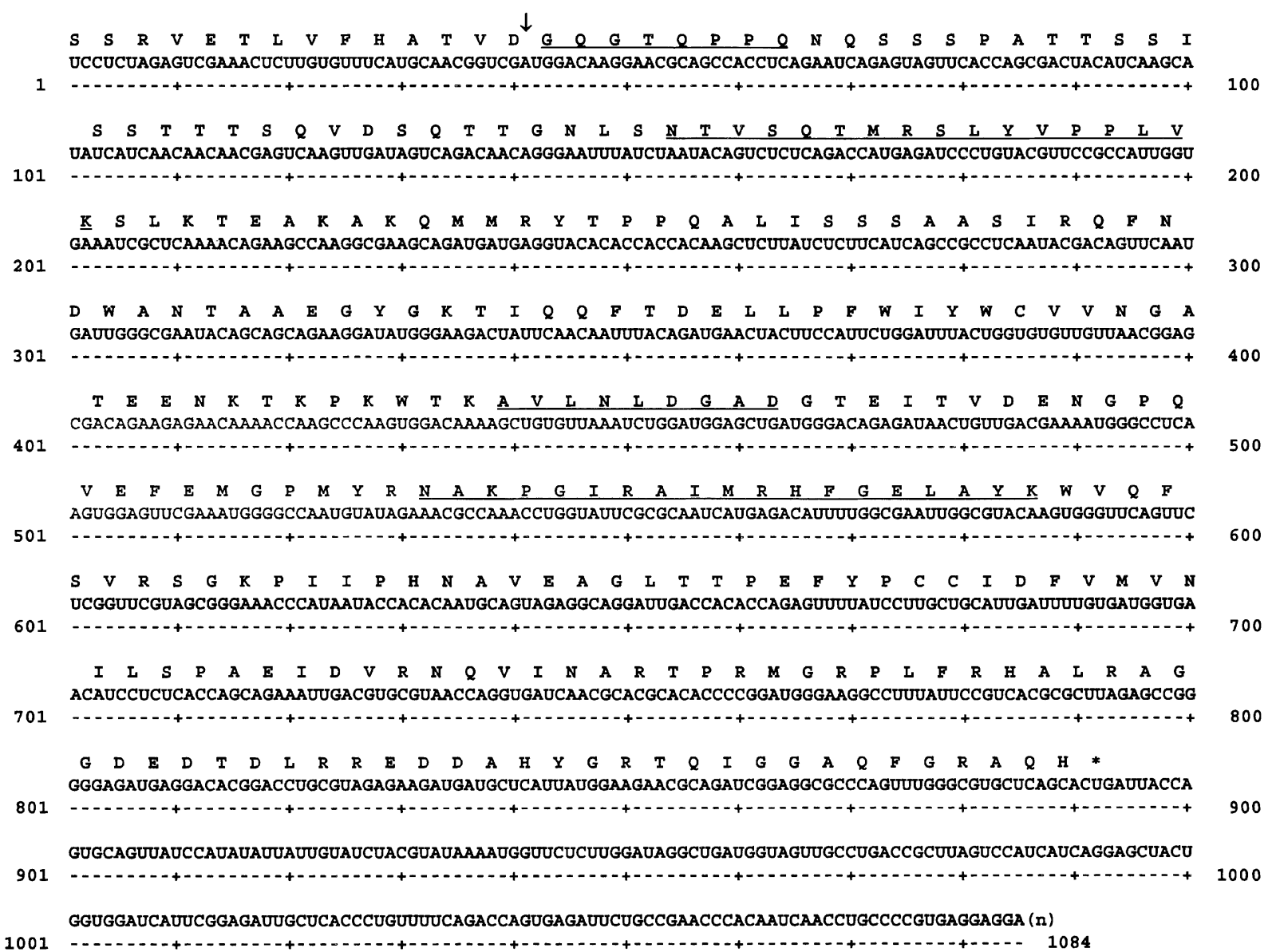

Fig. 3. Nucleotide and deduced amino acid sequence of the $3^{\prime}$ terminal region of the sugarcane viral RNA. The N-terminal amino acid sequence of the coat protein and tryptic peptides as determined by amino acid sequencing is underlined. The arrow indicates the putative cleavage site between NIb and coat protein for NIa protease

acid sequence determined from the coat protein and two of the tryptic peptides (TP 1 and TP 3 ) were identical to the deduced sequence at corresponding segments (underlined in Fig. 3). The N-terminal amino acid sequence of the coat protein is suggestive of a noval D-G cleavage site between the NIb and coat protein for the NIa protease. The size of the coat protein as deduced from the sequence data is $34 \mathrm{kDa}$ in contrast to the molecular weight as determined by SDS-PAGE (40 kDa). In order to account for this discrepancy the protein was stained for glycoproteins. Interestingly, the coat protein of the present isolate is a glycoprotein (Fig. 2b).

\section{Analysis of the viral genome}

The $3^{\prime}$ terminal 1084 nucleotides were compared with all the members of the Potyviridae and was found to be closely related to the recently described Tritimovirus 
(Potyviridae) sugarcane streak mosaic virus from Pakistan [7]. The overall identity with SCSMV at nucleotide level was $85.7 \%$. The $3^{\prime}$ UTR was better conserved than coat protein nucleotide sequence ( $94.3 \%$ and $85.5 \%$ identity, respectively). However, the deduced amino acid sequence of the coat protein of the present isolate showed $93.6 \%$ identity with SCSMV. These results suggest that the virus isolated from Andhra Pradesh is a strain of SCSMV. Complete genomic sequence of two other tritimoviruses [18] are known namely WSMV (AFO57533) and BrSMV (Z48506). Interestingly the deduced coat protein amino acid sequence of SCSMV-AP reported here and SCSMV from Pakistan [7] showed only 32.5\% and $31.3 \%$ identity with WSMV and $27.6 \%$ and $30.2 \%$ identity with BrSMV respectively. However, the two isolates did not show significant identity with any other members of the Potyviridae. The coat protein of the present isolate lacks the DAG present in aphid transmissible potyvirus coat protein. It also lacks the MVWCIENG motif present in the core region of the coat protein of most of the potyviruses. A heptapeptide RAIMRHF (also shown in Table 3) is the largest conserved stretch among the SCSMV, WSMV and BrSMV. Although the virus cross-reacted weakly with narcissus latent virus in DAC-ELISA and EBIA tests, no significant homology was observed between the coat protein sequences of the two viruses.

\section{Discussion}

The family Potyviridae is the largest and economically the most important group of plant viruses [25]. New strains and distinct viruses are constantly described and added to this ever growing taxon. There are now 6 genera of the family, they are Potyvirus, Bymovirus, Rymovirus, Ipomavirus, Macluravirus and Tritimovirus [18].

The present virus isolate has flexuous filamentous particle morphology (Fig. 1), pinwheel inclusions (data not shown), monopartite RNA genome and single capsid protein with $\mathrm{Mr} 40 \mathrm{kDa}$ which indicates its taxonomic affiliation to the family Potyviridae. The vectors involved in the spread of the virus are yet to be identified. Our initial attempts to transmit the virus by aphids (Aphis craccivora, Rhopalsiphum maidis) in non-persistent way were negative. The molecular weight of the coat protein was higher than the average molecular weight of well characterized potyviruses. The coat protein molecular weight of narcissus latent virus and maclura mosaic virus were also higher in the range of $39-40 \mathrm{kDa}$, although the deduced coat protein sequence of these viruses suggested a range of $32-34 \mathrm{kDa}$ [2]. Interestingly, the molecular weight as suggested by coat protein sequence in the present study was also lower than the estimated Mr on SDS-PAGE (Fig. 2a). The apparent increase in molecular weight and the results from PAS staining shows that it is a glycoprotein (Fig. 2b). This is the first report of a glycosylated coat protein among potyviruses. The DAC-ELISA results presented in this paper clearly demonstrate that the virus causing mosaic disease on sugarcane in India is antigenically distinct from sugarcane mosaic virus subgroup [8]. The virus appeared to be distantly related to narcissus latent virus. Treatment of intact virus 
with trypsin did not yield the trypsin resistant core as reported for potyviruses, but 4-5 distinct bands were obtained (Fig. 2a). N-terminal amino acid sequence of one of these peptides showed significant identity with the potyviral coat protein sequence (Table 3 ).

Amino acid sequence of coat proteins is being used to classify distinct potyviruses and its strains. It has been suggested that distinct potyviruses possess coat protein sequence identities less than $70 \%$ whereas strains of individual viruses possess identity greater than 90\% [23]. The $3^{\prime}$-untranslated sequence of potyviral RNA has great value in the identification of potyviruses and can be used to distinguish viruses from strains [5]. The 3'-1084 nucleotide sequence reported here is closely related to the recently reported Tritimovirus (Potyviridae) sugarcane streak mosaic virus [7]. Hall et al. [7] after extensive sequence analysis of SCSMV have suggested that this virus could be grouped along with wheat streak mosaic virus and brome streak mosaic virus belonging to the genus Rymovirus of Potyviridae. However, SCSMV CP sequence has only $31.3 \%$ and $30.2 \%$ identity with that of WSMV and BrSMV, respectively. Recently in the AAB Descriptions of Plant Viruses No. 245 [18] the genus Rymovirus has been split into Tritimovirus and Rymovirus. WSMV and BrSMV have been grouped under Tritimovirus genus. Hence, SCSMV could be grouped under the same genus.

Based on the above observations we would like to name the isolate described here as SCSMV-AP. The uncharacterized virus isolates from various locations (Uttar Pradesh, Maharashtra, Andhra Pradesh, Tamil Nadu and Karnataka states) in India cross-reacted with the antiserum to this virus isolate in ELISA and EBIA (data not shown). It is possible that these isolates are further strains of SCSMV. The N-terminus of SCSMV Pakistani isolate is blocked [7]. However, the $\mathrm{N}$-terminus is not blocked in SCSMV-AP and it reveals a novel D-G cleavage site between NIb/CP for NIa protease. Thus, the present study establishes that the mosaic disease in sugarcane in India is not caused by the strains of sugarcane mosaic virus subgroup but by the newly described Tritimovirus, sugarcane streak mosaic virus.

\section{Acknowledgements}

M. Hema and P. Sreenivasulu are greateful to USDA (PL 480 project No.IN-ARS-718) for financial assistance. This work was also supported by financial grant to H. S. Savithri from Department of Science and Technology and Department of Biotechnology, Government of India. We would like to thank Jeffrey Hall for making available the preprint of their paper. We thank Dr. K. S. Ravi, Center for Application of Molecular Biology to International Agriculture, Australia and Dr. D. J. Robinson, SCRI, Dundee for providing potyvirus group specific antiserum and antisera against narcissus latent virus. The assistance by Dr. Indi for the electron microscopic studies, Mr. G. S. Girish for glycoprotein staining, Mr. Srihari Reddy for amino acid sequencing, Ms. Savitha for automated DNA sequencing, and Mr. P. Elango for nucleotide sequence analysis, is gratefully acknowledged. We thank DBT, India for providing the facilities for amino acid and DNA sequencing and Bioinformatics at the Indian Institute of Science, Bangalore. 


\section{References}

1. Agnihotri VP (1996) Current sugarcane disease scenario and management strategies. Ind Phytopathol 49: 109-126

2. Badge J, Robinson DJ, Brunt AA, Foster GD (1997) 3'-terminal sequences of the RNA genomes of narcissus latent and maclura mosaic viruses suggest that they represent a new genus of the Potyviridae. J Gen Virol 78: 253-257

3. Brunt AA, Crabtree K, Dallwitz MJ, Gibbs AJ, Watson L (1996) Sugarcane mosaic virus. In: Viruses of Plants. CAB International, Wallingford

4. FAO (1997) Quarterly Bulletin of Statistics, Food and Agricultural Organization, Rome, No $10, \mathrm{p} 109$

5. Frenkel MJ, Ward CW, Shukla DD (1989) The use of $3^{\prime}$ non-coding sequence in the taxonomy of potyviruses: application to watermelon mosaic virus 2 and soybean mosaic virus. J Gen Virol 70: 2775-2783

6. Grunstein M, Hogness DS (1975) Colony hybridization: A method for the isolation of cloned DNAs that contain a specific gene. Proc Natl Acad Sci USA 72: 3691

7. Hall JS, Adams B, Parsons TJ, French R, Lane LC, Jensen SG (1999) Molecular cloning, sequencing and phylogenetic relationships of a new potyvirus; sugarcane streak mosaic virus, and a reevaluation of the classification of the Potyviridae. Mol Phylogen Evol (in press)

8. Hema M, Sreenivasulu P, Gopinath K, Kiranmai G, Satyanarayana T (1997) Partial characterization of a potyvirus causing mosaic disease of sugarcane in Andhra Pradesh. Ind J Virol 13: 125-129

9. Hobbs HA, Reddy DVR, Rajeswari R, Reddy AS (1987) Use of direct antigen coating method and protein-A coating ELISA procedures for detection of three peanut viruses. Plant Dis 71: 747-749

10. Hollings M, Brunt AA (1981) Potyvirus group. CMI/AAB Description of Plant Viruses. No 245

11. Jain RK, Rao GP, Varma A (1998) Present status of management of sugarcane mosaic virus. In: Hadidi A, Khetarpal RK, Koganezava H (eds) Plant virus disease control. American Publishing Company, Minnesota, pp 495-523

12. Koike H, Gillaspie AG (1989) Mosaic. In: Recaud C, Egar CB, Gillaspie AG, Hughes CG (eds) Diseases of sugarcane - major diseases. Elsevier, New York, pp 301-322

13. Kondaiah E, Nayudu MV (1985) Strain N- A new strain of sugarcane mosaic virus. Sugarcane 4: 11-14

14. Laemmli UK (1970) Cleavage of structural proteins during the assembly of the head of bacteriophage $\mathrm{T}_{4}$. Nature 227: 680-685

15. Madhulika M, Rao GP, Upadhyaya PP (1998) Identification and characterization of maize dwarf mosaic potyvirus in India. Ind J Virol 14: 75-79

16. Mishra A, McKimm-Breschkin JL, Xiao XW, Shukla DD (1997) A broad cross-reactive polyclonal antibody probe to detect members of the family Potyviridae. Ind J Virol 13: $15-22$

17. Murphy FA, Fauquet CM, Bishop DHL, Ghabrial SA, Jarvis AW, Martelli GP, Mayo MA, Summers MD (eds) (1995) Virus Taxonomy. Classification and Nomenclature of Viruses. Sixth Report of the International Committee on Taxonomy of Viruses. Springer, Wien New York (Arch Virol [Suppl] 10)

18. Potyviridae (1998) CMI/AAB Description No. 245. In: Adams MJ, Anteniw JF, Barker $\mathrm{H}$, Jones AT, Murant AF, Robinson D (eds) Description of plant viruses on CD-ROM. Association of Applied Biologists, Wellesbourne

19. Rao GP (1998) Identification of sugarcane mosaic potyvirus on sorghum and bajra in India. Ind J Virol 14: 81-84 
20. Sambrook J, Fritsch EF, Maniatis T (1989) Molecular cloning: a laboratory manual. Cold Spring Harbor Laboratory Press, New York

21. Sanger F, Nicklen S, Coulson AR (1977) DNA sequencing with chain termination inhibitors. Proc Natl Acad Sci USA 74: 5463-5467

22. Schagger H, Von Jagow G (1987) Tricine-Sodium dodecyl sulphate-polyacrylamide gel electrophoresis for the separation of proteins in the range from 1 to $100 \mathrm{kDa}$. Anal Biochem 166: 368-379

23. Shukla DD, Ward CW (1989) Identification and classification of potyviruses on the basis of coat protein sequence data and serology. Arch Virol 106: 171-200

24. Shukla DD, Frenkel MJ, McKern NM, Ward CW, Jilka J, Tosic M, Ford RE (1992) Present status of the sugarcane mosaic subgroup of potyviruses. Arch Virol [Suppl] 5: 363-373

25. Shukla DD, Ward CW, Brunt AA (1994) The Potyviridae. CAB International, Wallingford

26. Tsugita A, Hirashima A (1972) Isolation and properties of virus proteins. In: Kado CI, Agarwal HO (eds) Principles and techniques in plant virology. Van Nostrand Reinhold, New York, pp 413-443

27. Ward CW, McKern NM, Frenkel MJ, Shukla DD (1992) Sequence data as the major criterion for potyvirus classification. Arch Virol [Suppl] 3: 283-297

28. Yang ZN, Mirkov TE (1997) Sequence and relationships of sugarcane mosaic and sorghum mosaic virus strains and development of RT-PCR based RFLPs for strain discrimination. Phytopathlogy 87: 932-939

29. Zaccharius RM, Zell TE (1969) Glycoprotein staining following electrophoresis on acrylamide gels. Anal Biochem 30: 148-151

30. Zaitlin M (1979) The RNA of monopartite plant viruses. In: Hall TC, Davies JW (eds) Nucleic acids in plants, vol 2. CRC Press, Boca Raton, pp 31-64

Authors' address: Dr. H. S. Savithri, Department of Biochemistry, Indian Institute of Science, Bangalore-560 012, Karnataka, India.

Received August 7, 1998 